\title{
Copolythiophene-based water-gated organic field-effect transistors for biosensing
}

Clément Suspéne, Benoit Piro, Steeve Reisberg, Minh-Chau Pham, Henrik Toss, Magnus Berggren, Abderrahim Yassar and Gilles Horrowitz

\section{Linköping University Post Print}

N.B.: When citing this work, cite the original article.

Original Publication:

Clément Suspéne, Benoit Piro, Steeve Reisberg, Minh-Chau Pham, Henrik Toss, Magnus Berggren, Abderrahim Yassar and Gilles Horrowitz, Copolythiophene-based water-gated organic field-effect transistors for biosensing, 2013, Journal of Materials Chemistry B.

http://dx.doi.org/10.1039/C3TB00525A

Copyright: Royal Society of Chemistry http://www.rsc.org/

Postprint available at: Linköping University Electronic Press

http://urn.kb.se/resolve?urn=urn:nbn:se:liu:diva-89994 


\title{
Copolythiophene-based water-gated organic field-effect transistors for biosensing
}

\author{
Clément Suspène, ${ }^{a}$ Benoit Piro, $*^{a}$ Steeve Reisberg, ${ }^{a}$ Minh-Chau Pham, ${ }^{a}$ Henrik Toss, ${ }^{b}$ Magnus \\ Berggren, ${ }^{b}$ Abderrahim Yassar ${ }^{c}$ and Gilles Horowitz ${ }^{c}$
}

${ }_{5}$ Received (in XXX, XXX) 12th December 2012, Accepted 13th February 2013

DOI: 10.1039/C3TB00525A

This paper reports on the sensing of proteins by water-gated organic field-effect transistors. As a proofof-concept, streptavidin and avidin were used, with a biotinylated polymer as the active sensing material. The latter is a copolythiophene modified to graft biotin by peptidic coupling. After characterization of its 10 structure, it was integrated as the channel material into transistors and interactions with several proteins were investigated. Non-specific interactions were reduced when the polymer surface was pretreated with 1-octanol. In this case, human serum albumin had no effect on the transistor characteristics whereas avidin and streptavidin led to a decrease of the drain current.

\section{Introduction}

15 A biological sensor is an analytical device for the detection of biological analytes, like proteins, DNA, antibodies or enzymes. Today, low-power and low-cost portable devices incorporating highly sensitive sensors are needed in many fields, including agriculture industry, medical analysis, homeland security or 20 environmental monitoring. Among these sensors, those built on organic field-effect transistors (OFETs) and on the simple change of the output signals in response to the binding of analytes, are of great interest. ${ }^{1,2}$ The advantages of OFETs are biocompatibility, easiness to manufacture, solution processability, low power 25 consumption and the simplicity and high precision of an electrical signal. Several examples demonstrating the use of OFETs in vapour sensors have been described, involving the use of a fingerprint response $\mathrm{s}^{3}$ or the incorporation of selective detection layers. ${ }^{4} 5$ Because biological analytes and biologically derived 30 recognition elements are only active in aqueous media, OFET operation with the active semiconducting material in direct contact with both stationary and flowing water has been explored $^{6}$ and stable operation in aqueous solution for a range of different organic semiconductors has been reported. ${ }^{7-10}$ For

35 example, a real-time and in situ selective detection scheme with short-chain DNA targets employing organic transistors as the electrical transducer was recently proposed by Bao's group. ${ }^{11}$

${ }^{a}$ Univ. Paris Diderot, Sorbonne Paris Cité, ITODYS, UMR 7086 CNRS, 4015 rue J-A de Baïf, 75205 Paris Cedex 13, France; Tel:+33 157277223; E-mail:piro@univ-paris-diderot.fr

${ }^{\mathrm{b}}$ Department of Science and Technology (ITN), Linköpings Universitet, Campus Norrköping, Bredgatan 34, 60174 Norrköping (Sweden); Tel: +46 (0)11 3636 37; E-mail: magnus.berggren@liu.se $45^{c}$ LPICM, UMR CNRS 7647, Ecole Polytechnique, Route de Saclay, 91128 Palaiseau (France); $\quad$ Tel +33 169334354; E-mail: gilles.horowitz@polytechnique.edu

$\dagger$ Electronic Supplementary Information (ESI) available:.FT-IR and ${ }^{1} \mathrm{H}$ NMR of P3HT-biotin. See DOI: 10.1039/b000000x/

50

Khan et al. reported sensors based on a pentacene layer passivated with either a layer of perfluorinated molecules ${ }^{12}$ or copper phthalocyanine. ${ }^{13}$ These works provide good bases on using OFET made of conventional organic semiconductors in 55 highly sensitive, low cost, selective and label-free biological sensor. A P3HT-based device, sensitive to ions and stable in complex media, was recently described by Scarpa et al. and showed potential applications in disposable and low-cost biosensors. ${ }^{14}$ In particular, the semiconducting material exhibited 60 constant transport properties when exposed to a phosphate buffer saline (PBS) solution for two hours.

Electrolyte-gated OFETs offer a particular architecture where the gate dielectric is replaced by an electrolyte, like water, on top of the semiconductor layer. ${ }^{15}$ In this case, the metallic gate is 65 constituted by a gold or platinum wire directly in contact with the solution. The large electrical double-layer capacitance that forms at the organic semiconductor/electrolyte interface enables the transistors to operate at very low voltages (below $1 \mathrm{~V}$ ) where only negligible electrochemical reactions occur. This opens up to 70 biosensing applications in aqueous media, as first described for DNA detection with a polythiophene derivatives as the semiconductor. $^{16}$

Due to its strong affinity $\left(K_{\mathrm{a}} \approx 10^{15} \mathrm{M}^{-1}\right),{ }^{17-19}$ the avidin/biotin couple was often used as a model in protein sensors. Devices 75 incorporating biotin-functionalized silicon nanowires ${ }^{20}$ or carbon nanotubes $^{21}$ were indeed prepared for the detection of avidin and/or streptavidin at different concentrations. The bioprobe was 
grafted either directly on the semiconductor or on a passivation polymer layer. Biotin was also immobilized on polythiophene layers, through electrostatic interactions or by covalent attachment, in order to detect electrochemically, ${ }^{22}$ ${ }^{5}$ photoelectrochemically ${ }^{23}$ or by change of chemoresistivity ${ }^{24}$ streptavidin/avidin complexation. To our surprise, we found only one reference in the literature dealing with the detection of those proteins by transistors operating in the field-effect mode where biotin is covalently attached to a semiconducting polymer layer. 10 The active material is in this case a polyfluorene-copolythiophene polymer functionalized with biotin hydrazide. The electrical characterizations were performed in the dry state at quite high voltages (gate voltage $\mathrm{V}_{\mathrm{G}}=-40 \mathrm{~V}$ ). ${ }^{25}$

Here, we report on the sensing of streptavidin and avidin by 15 biotin-functionalized water-gated OFETs, using a random copolythiophene derived from $\mathrm{P} 3 \mathrm{HT}$ as semiconductor. This copolymer, P3HT-biotin, bears approximately $8 \% \mathrm{~mol} / \mathrm{mol}$ of biotin groups. To prevent non-specific interactions with proteins, Tween 20 and 1-octanol were adsorbed on the P3HT copolymer 20 and evaluated.

\section{Experimental}

\section{Materials and characterization methods}

All chemical reagents, solvents, 1-octanol, Tween 20, streptavidin, avidin, human serum albumin (HSA) and phosphate 25 buffer saline (PBS) tablets were purchased from Sigma-Aldrich and used without further purification. Deionized water $(18 \mathrm{M} \Omega$ $\mathrm{cm})$ was obtained from an Elga DV35 water purification system. $1 \mathrm{mM}$ PBS solution was prepared from commercial tablets (Sigma) dissolved in deionized water. Streptavidin, avidin and 30 HSA solutions $(1.67 \mu \mathrm{M})$ were made by dissolving $0.1 \mathrm{mg}$ protein into $1 \mathrm{~mL}$ of $1 \mathrm{mM}$ PBS solution.

FT-IR spectra were recorded in ATR mode on a Perkin Elmer Spectrum 100. ${ }^{1} \mathrm{H}$ NMR spectra were recorded on a Bruker 400 $\mathrm{MHz}$ spectrometer; chemical shifts $(\delta)$ are given relative to 35 residual solvent peaks. Molecular weights (MWs) and polydispersity indices (PDIs) were measured by GPC on a Dionex UltiMate 3000 equipped with an absorbance detector (UV, $\lambda=254 \mathrm{~nm}$ ), pre-column filters and polystyrene gel columns based on a conventional calibration curve using 40 polystyrene standards. THF was used as a carrier solvent at a flow rate of $1.0 \mathrm{~mL} \mathrm{~min}^{-1}$ at room temperature. I-V characteristics were measured in air at room temperature using a Keithley 4200SCS semiconductor characterization system and a Karl Suss manual probe station.

45 Impedance measurements were performed on $\mathrm{Au} /$ water/polymer/Au capacitors in which the rectangular $(1 \mathrm{~mm}$ $\times 1 \mathrm{~mm}$ ) Au bottom electrode had much smaller (at least ten times) contact area than the $\mathrm{Au}$ top electrode. Impedance was recorded for an $\mathrm{AC}$ voltage of $0.1 \mathrm{~V}$ with an Alpha high50 resolution dielectric analyzer (Novocontrol GmbH). Frequencies were swept from high to low values.

Output and transfer curves were recorded at an estimated speed of $160-170 \mathrm{mV} \mathrm{s}^{-1}$. The $I_{\text {on }} / I_{\text {off }}$ ratio is estimated at source-drain voltage $V_{D}=-0.6 \mathrm{~V}$, the mobility $\mu$ and threshold voltage $V_{T}$ are 55 extracted under the assumption of square-law behaviour with mobility being derived from the slope of the partial sweep and threshold voltage arising from the $x$-intercept of the square root of drain current $I_{D}$. The sub-threshold swing is extracted from an exponential regression of the transfer curve at $V_{D}=-0.6 \mathrm{~V}$.

60 The protocol employed to characterize interactions between proteins and biotin consists for a given transistor in a first measurement carried out with a $1 \mathrm{mM}$ PBS droplet, then replaced by another one containing streptavidin, avidin or albumin in PBS and incubation in a climate chamber $\left(90 \%\right.$ humidity, $\left.25^{\circ} \mathrm{C}\right)$ for ${ }_{65} 30 \mathrm{~min}$, rinsing with DI water and drying with argon, and finally of a second measurement with a new $1 \mathrm{mM}$ PBS droplet. The results are analyzed by plotting the square root of the absolute value of $I_{D}$ versus $V_{G}$ at $V_{D}=-0.6 \mathrm{~V}$ and by calculating the variation of the drain current $\Delta I_{D} / I_{D O}$ upon addition of the analyte, 70 where $\Delta I_{D}=I_{\text {Danalyte }} I_{D 0}$. $I_{\text {Danalyte }}$ and $I_{D O}$ are the current after and before exposure to the analyte, respectively. $I_{D}$ is measured at $V_{G}$ $=-0.6 \mathrm{~V}$

\section{OFET fabrication}

The transistors were built in bottom contact, top gate 75 configuration. The substrates were prepared in Linköping University as follows: a $50 \AA$ thick adhesion layer of titanium and a $500 \AA$ thick layer of gold were thermally evaporated onto doped silicon wafers with a thick, thermally grown oxide layer $(1000 \mathrm{~nm})$. Source and drain gold electrodes were then patterned 80 using standard photolithography procedures. The transistor channel length and width used were $\mathrm{L}=10 \mu \mathrm{m}$ and $\mathrm{W}=10000 \mu \mathrm{m}$, respectively. Adequate cleaning of the substrates is necessary after the lift-off process and before deposition of the semiconducting material. The cleaning procedure consists in 85 sonication in an acetone bath for $3 \mathrm{~min}$, followed by an intense rinsing with isopropanol, drying with argon then exposed to UV/ozone treatment for $45 \mathrm{~min}$. The substrates were finally baked at $100{ }^{\circ} \mathrm{C}$ for $30 \mathrm{~min}$ to remove excess moisture.

Semiconductor thin films were prepared with a Polos ${ }_{90}$ MCD200-NPP spin coater. P3HT-biotin was deposited onto gold by spin-coating P3HT-biotin copolymer in chloroform at a concentration of $5 \mathrm{mg} \mathrm{mL}^{-1}$. This solution was previously filtered through a $0.2 \mu \mathrm{m}$ PTFE filter to remove any large particles, then spun on the substrates at a speed of $3000 \mathrm{rpm}$ for $9530 \mathrm{~s}$. Substrates were immediately annealed at $120^{\circ} \mathrm{C}$ for $2 \mathrm{~h}$.

The electrolyte droplets (DI water or PBS) were deposited on the channel with a calibrated microsyringe. A volume of $3 \mu \mathrm{L}$ was chosen so that a droplet can completely cover the channel. The gate electrode consisted of a gold wire $(\varnothing=1 \mathrm{~mm}$, purchased 100 from Goodfellow) dipped into the electrolyte droplet.

\section{Synthesis}

Random P3HT-COOPr15. Propyl 5-(2-(2,5dibromothiophen-3-yl)ethoxy)pentanoate ${ }^{26}$ (525 mg, $1.23 \mathrm{mmol}$ ) and 2,5-dibromo-3-hexylthiophene (2.4 g, $7.38 \mathrm{mmol})$ were 105 dissolved in $50 \mathrm{~mL}$ of anhydrous THF in a $100 \mathrm{~mL}$ three-necked flame-dried round-bottom flask under argon. After cooling at $50{ }^{\circ} \mathrm{C}$, isopropylmagnesium bromide $\left({ }^{\mathrm{i}} \mathrm{PrMgBr}, 3 \mathrm{M}\right.$ in 2methylTHF, $3.2 \mathrm{~mL}, 9.5 \mathrm{mmol}$ ) was added via a syringe. The reaction medium was maintained at $-50{ }^{\circ} \mathrm{C}$ under stirring for $2 \mathrm{~h}$. 110 After warming at room temperature, [1,3Bis(diphenylphosphino)propane]dichloronickel(II) (Ni(dppp) $\mathrm{Cl}_{2}$, $23.3 \mathrm{mg}, 0.5 \mathrm{~mol} \% /$ monomers) was added in one portion. The mixture was stirred at room temperature for $15 \mathrm{~h}$ and the reaction 
was then quenched by pouring into $300 \mathrm{~mL}$ of methanol. The precipitated polymer was filtered into a Soxhlet thimble and sequentially extracted with methanol, diethyl ether and chloroform. The chloroform fraction was evaporated to dryness 5 to afford the desired copolymer as a violet solid $(630 \mathrm{mg}$, $\eta=40 \%)$.

${ }^{1} \mathrm{H}$ NMR $\left(400 \mathrm{MHz}, \mathrm{CDCl}_{3}, 300 \mathrm{~K}\right): \delta(\mathrm{ppm})=0.91\left(\mathrm{t}, \mathrm{CH}_{3}\right)$, $1.24-1.71\left(\mathrm{~m}, \mathrm{CH}_{2} \mathrm{CH}_{2} \mathrm{CH}_{2}+\mathrm{CH}_{2} \mathrm{CH}_{2} \mathrm{CH}_{3}\right), 2.34$ (t, $\left.\mathrm{CH}_{2} \mathrm{COO}\right)$, 2.80 (t, thiophene $\underline{H}_{2}$ (P3HT part)), $3.09\left(\mathrm{t},{ }^{3} J=7.0 \mathrm{~Hz}\right.$, 10 thiophene $\underline{\mathrm{H}}_{2}$ (COOPr15 part)), 3.50 (t, $\left.\mathrm{OCH}_{2} \mathrm{CH}_{2} \mathrm{CH}_{2}\right), 3.71$ (t, ${ }^{3} \mathrm{~J}=7.0 \mathrm{~Hz}, \mathrm{OCH}_{2} \mathrm{CH}_{2}$ thiophene), $4.01\left(\mathrm{t}, \mathrm{OCH}_{2} \mathrm{CH}_{2} \mathrm{CH}_{3}\right), 6.98$ (s, $\underline{\mathrm{H}}_{\text {thiophene }}$ (HT-HT triad P3HT part)), 7.02 (s, $\mathrm{CH}_{\text {thiophene }}$ (HTHT other triad)), 7.04 (s, $\underline{\mathrm{H}}_{\text {thiophene }}$ (HT-HT other triad)), 7.07 (s, $\mathrm{C}_{\text {thiophene }}$ (HT-HT triad COOPr15 part)). The ratio of COOPr15 15 part:P3HT part estimated from ${ }^{1} \mathrm{H}$ NMR is 15:85. IR (ATR, $\mathrm{cm}^{-}$ $\left.{ }^{1}\right): 3054\left(v\right.$ C- $\left.\mathrm{H}_{\text {thiophene }}\right), 2927\left(v_{\text {as }} \mathrm{C}-\mathrm{H}\right), 2856\left(v_{\mathrm{s}} \mathrm{C}-\mathrm{H}\right), 1736(v$ $\mathrm{C}=\mathrm{O}), 1514\left(v_{\mathrm{as}} \mathrm{C}=\mathrm{C}\right), 1458\left(v_{\mathrm{s}} \mathrm{C}=\mathrm{C}\right), 1112$ and $1166(v \mathrm{C}-\mathrm{O})$, $825\left(\gamma \mathrm{C}-\mathrm{H}_{\text {thiophene }}\right)$.

20 Random P3HT-COOH15. To a solution of P3HT-COOPr15 (540 mg, $2.9 \mathrm{mmol}$ ) in $50 \mathrm{~mL}$ of THF in a $100 \mathrm{~mL}$ round-bottom flask was added a solution of sodium hydroxide (10 M, $3 \mathrm{~mL})$. The reaction mixture was heated with stirring at $70{ }^{\circ} \mathrm{C}$ for $15 \mathrm{~h}$. After cooling to room temperature, the copolymer was 25 reprotonated with a $2 \mathrm{M}$ solution of hydrochloric acid (37\%). The resulting solution was then poured into $300 \mathrm{~mL}$ of methanol. The precipitated polymer was filtered into a Soxhlet thimble and sequentially extracted with methanol and chloroform. The chloroform fraction was evaporated to dryness to afford the 30 desired copolymer as a violet solid $(310 \mathrm{mg}, \eta=60 \%)$.

GPC (PS calibration, THF, $1 \mathrm{~mL} \mathrm{~min}^{-1}$, room temperature): $\mathrm{M}_{w}=18000 \mathrm{~g} \mathrm{~mol}^{-1}, \mathrm{M}_{n}=14500 \mathrm{~g} \mathrm{~mol}^{-1}$, PDI $=1.24 .{ }^{1} \mathrm{H} \mathrm{NMR}$ $\left(400 \mathrm{MHz}, \mathrm{CDCl}_{3}, 300 \mathrm{~K}\right): \delta(\mathrm{ppm})=0.91\left(\mathrm{t}, \mathrm{CH}_{2} \underline{\mathrm{C}}_{3}\right), 1.24-$ $1.71\left(\mathrm{~m}, \mathrm{CH}_{2} \underline{\mathrm{C}}_{2} \mathrm{CH}_{2}+\mathrm{CH}_{2} \underline{\mathrm{CH}}_{2} \mathrm{CH}_{3}\right), 2.29$ (t, $\left.\mathrm{CH}_{2} \mathrm{COOH}\right), 2.80$ 35 (t, thiopheneC $\left.\underline{\mathrm{H}}_{2}(\mathrm{P} 3 \mathrm{HT})\right), 3.09\left(\mathrm{t},{ }^{3} \mathrm{~J}=7.0 \mathrm{~Hz}\right.$, thiophene $\underline{\mathrm{H}}_{2}$ (COOH15 part)), $3.49\left(\mathrm{t}, \mathrm{OCH}_{2} \mathrm{CH}_{2} \mathrm{CH}_{2}\right), 3.70\left(\mathrm{t},{ }^{3} \mathrm{~J}=7.0 \mathrm{~Hz}\right.$, $\mathrm{OCH}_{2} \mathrm{CH}_{2}$ thiophene), 6.98 (s, $\underline{\mathrm{C}}_{\text {thiophene }}$ (HT-HT triad P3HT part)), 7.02 (s, $\underline{\mathrm{CH}}_{\text {thiophene }}$ (HT-HT other triad)), 7.04 (s, $\underline{\mathrm{C}}_{\text {thiophene }}$ (HT-HT other triad)), 7.07 (s, $\mathrm{CH}_{\text {thiophene }}$ (HT-HT triad COOH15 ${ }_{40}$ part)). The ratio of COOH15 part:P3HT part estimated from ${ }^{1} \mathrm{H}$ NMR is 15:85. IR (ATR, $\left.\mathrm{cm}^{-1}\right): 3056\left(v \mathrm{C}-\mathrm{H}_{\text {thiophene }}\right), 2926\left(\mathrm{v}_{\mathrm{as}} \mathrm{C}-\right.$ $\mathrm{H}), 2857\left(v_{\mathrm{s}} \mathrm{C}-\mathrm{H}\right), 1705(\mathrm{v} \mathrm{C}=\mathrm{O}), 1509\left(v_{\mathrm{as}} \mathrm{C}=\mathrm{C}\right), 1456\left(v_{\mathrm{s}}\right.$ $\mathrm{C}=\mathrm{C}), 1235$ ( $\vee \mathrm{C}-\mathrm{O}), 820\left(\gamma \mathrm{C}-\mathrm{H}_{\text {thiophene }}\right)$.

45 Random P3HT-biotin. To a solution of random P3HTCOOH15 (145 mg, $0.83 \mathrm{mmol})$ and $N$-hydroxysuccinimide (NHS, $28.6 \mathrm{mg}, 0.25 \mathrm{mmol}$ ) in $50 \mathrm{~mL}$ of $\mathrm{CHCl}_{3}$ in a $100 \mathrm{~mL}$ round-bottom flask under argon were successively added $\mathrm{N}$-(3dimethylaminopropyl)- $N$ '-ethylcarbodiimide hydrochloride 50 (EDC. $\mathrm{HCl}, 26 \mathrm{mg}, 0.14 \mathrm{mmol}$ ) and 4-(dimethylamino)pyridine (DMAP, $18 \mathrm{mg}, 0.15 \mathrm{mmol}$ ). The reaction mixture was stirred at room temperature in the dark under argon for $15 \mathrm{~h}$. In a separate flask, to a solution of biotin ethylenediamine hydrobromide (50 mg, $0.14 \mathrm{mmol}$ ) in $5 \mathrm{~mL}$ of DMF was added DMAP $55(30.7 \mathrm{mg}, \quad 0.25 \mathrm{mmol})$. The mixture was stirred at room temperature for $5 \mathrm{~min}$. The solution of biotin ethylenediamine was then added to the copolymer solution and the mixture was stirred at room temperature in the dark under argon for $24 \mathrm{~h}$. The resulting solution was then poured into $300 \mathrm{~mL}$ of methanol. The 60 precipitated polymer was filtered into a Soxhlet thimble and sequentially extracted with methanol and chloroform. The chloroform fraction was evaporated to dryness to afford the desired functionalized copolymer as a violet solid $(110 \mathrm{mg}$, $\eta=62 \%)$.

65 GPC (PS calibration, THF, $1 \mathrm{~mL} \mathrm{~min}^{-1}$, room temperature):
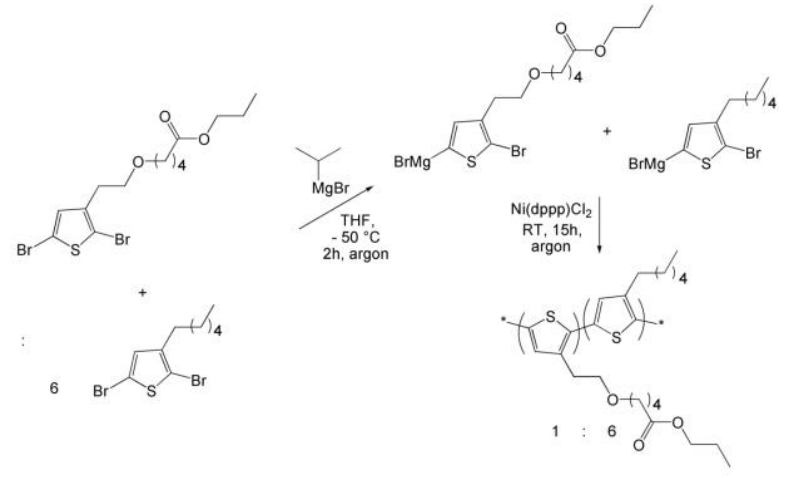

P3HT-COOPr15

Scheme 1: Synthesis of random P3HT-COOPr15
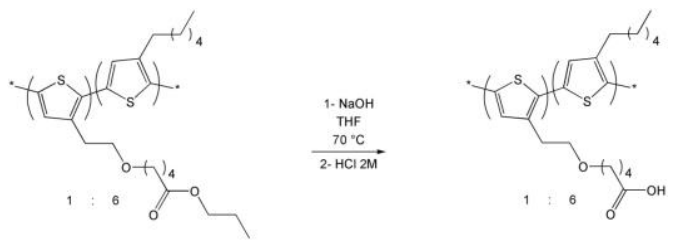

P3HT-COOPr15

P3HT-COOH15

Scheme 2: Synthesis of random P3HT-COOH15

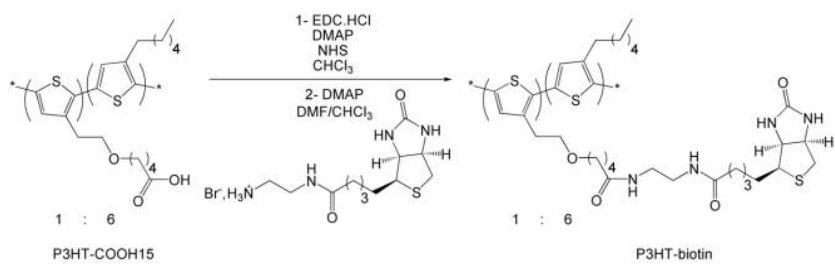

Scheme 3: Synthesis of random P3HT-biotin

$\mathrm{M}_{w}=13200 \mathrm{~g} \mathrm{~mol}^{-1}, \mathrm{M}_{n}=10200 \mathrm{~g} \mathrm{~mol}^{-1}, \mathrm{PDI}=1.29$.

${ }^{1} \mathrm{H}$ NMR $\left(400 \mathrm{MHz}, \mathrm{CDCl}_{3}, 300 \mathrm{~K}\right): \delta(\mathrm{ppm})=0.91\left(\mathrm{t}, \mathrm{CH}_{2} \mathrm{CH}_{3}\right)$, $1.25-1.74\left(\mathrm{~m}, \mathrm{CHCH}_{2} \mathrm{CH}_{2}+\mathrm{CH}_{2} \underline{\mathrm{CH}}_{2} \mathrm{CH}_{2}+\mathrm{CH}_{2} \underline{\mathrm{CH}}_{2} \mathrm{CH}_{3}\right), 2.17$ $75-2.45\left(\mathrm{~m}, \underline{\mathrm{CH}}_{2} \mathrm{CONH}+\mathrm{NHC}_{2} \underline{\mathrm{C}}_{2} \mathrm{NH}\right), 2.52\left(\mathrm{~m}, \mathrm{CHCH}_{2} \mathrm{~S}\right)$, 2.80 (m, thiopheneC $\underline{\mathrm{H}}_{2}$ (P3HT part) $\left.+\mathrm{CHC}_{2} \mathrm{~S}\right), 3.06(\mathrm{t}$,

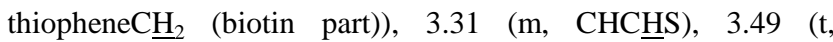
$\left.\mathrm{OCH}_{2} \mathrm{CH}_{2} \mathrm{CH}_{2}\right), \quad 3.70 \quad\left(\mathrm{t}, \quad \mathrm{OCH}_{2} \mathrm{CH}_{2}\right.$ thiophene), 4.29 (m, $\mathrm{NHCHCH}), 4.46$ (m, NHCHCH$\left.{ }_{2}\right), 6.50$ (s, $\left.\mathrm{CH}_{2} \mathrm{CHNHCO}\right), 6.64$ 80 (s, CHCHNHCO), 6.98 (s, $\underline{\mathrm{CH}}_{\text {thiophene }}$ (HT-HT triad P3HT part)), 7.02 (s, $\underline{\mathrm{C}}_{\text {thiophene }}$ (HT-HT other triad)), 7.04 (s, $\underline{\mathrm{CH}}_{\text {thiophene }}$ (HTHT other triad)), 7.07 (s, $\underline{\mathrm{CH}}_{\text {thiophene }}$ (HT-HT triad biotin part)), $8.02\left(\mathrm{t}, \mathrm{CONHCH}_{2}\right)$. IR $\left(\mathrm{ATR}, \mathrm{cm}^{-1}\right): 3280(v \mathrm{~N}-\mathrm{H}), 3059(v \mathrm{C}-$ $\left.\mathrm{H}_{\text {thiophene }}\right), 2920\left(v_{\text {as }} \mathrm{C}-\mathrm{H}\right), 2856\left(v_{\mathrm{s}} \mathrm{C}-\mathrm{H}\right), 1652(v \mathrm{C}=\mathrm{O}), 1548(\delta$ $85 \mathrm{~N}-\mathrm{H}), 1511\left(v_{\mathrm{as}} \mathrm{C}=\mathrm{C}\right), 1456\left(v_{\mathrm{s}} \mathrm{C}=\mathrm{C}\right), 1112(v \mathrm{C}-\mathrm{O}), 822(\gamma \mathrm{C}-$ $\mathrm{H}_{\text {thiophene) }}$.

\section{Results and discussion}

\section{Synthesis and characterization of P3HT-biotin}

The copolymer P3HT-biotin was prepared by introduction of 
biotin on a random copolymer carrying carboxylic acid terminated side chains. P3HT-COOH15 was synthesized following a procedure previously reported. ${ }^{26-28}$ The random copolymer, poly([3-hexylthiophene-2,5-diyl]-co-[3-(6-ethyl5 ethoxy-pentanoate)thiophene-2,5-diyl]), P3HT-COOPr15, was prepared by mixing the Grignard derivative of propyl 5-(2-(2,5dibromothiophen-3-yl)ethoxy)pentanoate with (5-bromo-4hexylthiophen-2-yl)magnesium bromide, at a molar ratio of 1:6.

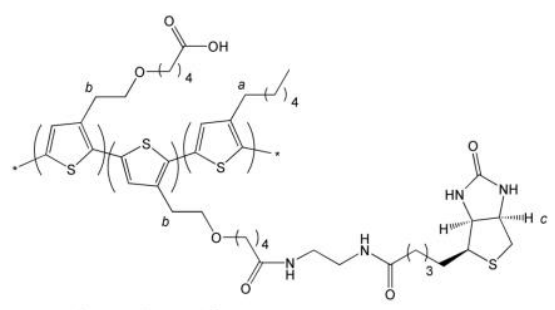

Figure 1: Structure of P3HT-biotin deduced from the 1H NMR spectrum

Polymerization was initiated by addition of a catalytic amount of $\mathrm{Ni}(\mathrm{dppp}) \mathrm{Cl}_{2}$, as described on Scheme 1 .

In a second step, saponification of P3HT-COOPr15 followed 15 by an acidic treatment afforded P3HT-COOH15, as shown on Scheme 2. This material bears around $14-15 \%$ of carboxylic acid groups randomly distributed into P3HT. The random copolymer P3HT-biotin was finally prepared as described on Scheme 3. Biotin was introduced in two steps by activation of the ${ }_{20} \mathrm{COOH}$ groups with NHS and then reaction with biotin ethylenediamine. The resulting biotinylated copolymer was purified by sequential Soxhlet extraction using methanol and chloroform. The isolated copolymer structure is not exactly the one shown on Scheme 3 as the introduction of biotin has not run 25 to completion. This could be explained by the low solubility of the biotin precursor in chloroform.

The FT-IR spectrum of the copolymer is given in ESI. ${ }^{\dagger}$ The band at $1652 \mathrm{~cm}^{-1}$ is assigned to the $\mathrm{C}=\mathrm{O}$ stretching vibration of the secondary amide group but a band is also present at $1700 \mathrm{~cm}^{-}$

${ }_{30}{ }^{1}$, assigned to the $\mathrm{C}=\mathrm{O}$ stretching vibration of the carboxylic acid group. The amount of biotin grafted on the copolymer is determined with the help of the ${ }^{1} \mathrm{H}$ NMR spectrum (see ${ }^{1} \mathrm{H}$ NMR data given in $\mathrm{ESI}^{\dagger}$ ). Integration of the peaks located at 2.80, 3.08 and $4.46 \mathrm{ppm}$, respectively assigned to the $\mathrm{CH}_{2}$ groups 35 linked to the thiophene rings for the P3HT part ( $a$, Figure 1), of the peaks from the $\mathrm{CH}_{2}$ groups linked to the thiophene rings bearing $\mathrm{COOH}$ groups or biotin ( $b$, Figure 1) and of the peak from a proton on the biotin core ( $c$, Figure 1$)$ indicates that the yield of the biotin grafting is ca. 50\% and that the structure of the 40 copolymer, bearing approximately $8 \%$ of biotin groups, is close to the one described in Figure 1.

The presence of four peaks in the aromatic area at 6.98, 7.02, 7.04 and $7.07 \mathrm{ppm}$, assigned to different triads, confirms the statistical distribution of the monomers in the polymer chain. ${ }^{26,27}$ 45 The interest of a random copolymer instead of a block copolymer is that the biotin groups are not located in the same polymer part but are dispersed over the whole chain, so that they are more accessible to big proteins such as (strept)avidin.

It is noteworthy to point out that the GPC analysis of the 50 chloroform fractions for P3HT-biotin show lower $\mathbf{M}_{w}$ and $\mathbf{M}_{n}$ values than for P3HT-COOH15. This could be explained by the fact that the heaviest polymer chains are no longer soluble when bearing biotin groups.

Prior to transistor characterization, impedance spectroscopy 55 was performed on Au/water/P3HT-biotin/Au structures. Figure 2 shows the frequency dependence of the effective capacitance and

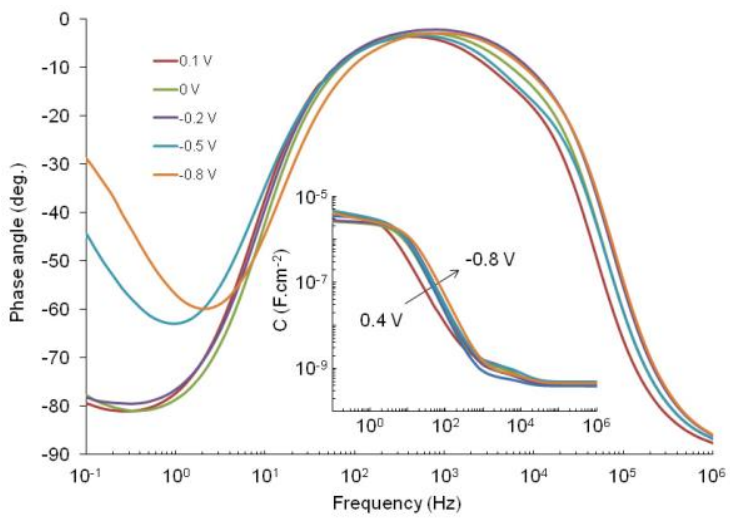

Figure 2: Phase angle and parallel capacitance (inset) versus frequency for a Au/water/P3HT-biotin/Au capacitor at five different gate voltages

60 of the phase angle. The effective capacitance was extracted by using a simple equivalent circuit including a capacitor connected in parallel to a resistor.

The phase angle of the impedance at frequencies above $100 \mathrm{kHz}$ is close to $-90^{\circ}$ showing that the capacitance exhibits 65 dipolar relaxations. A large dielectric increment is noticeable between $5 \mathrm{~Hz}$ and $50 \mathrm{kHz}$ (inset); below $5 \mathrm{~Hz}$ a saturation of the capacitance value is observed, indicating that dense electric double layers have been created at both electrodes. The associated capacitance $\left(\mathrm{C}_{\mathrm{P} 3 \mathrm{HT} \text {-biotin }}=2-6 \mu \mathrm{F} \mathrm{cm}{ }^{-2}\right)$ agrees well 70 with results obtained in the literature for gold and hydrophobic semiconductors in contact with aqueous electrolytes. ${ }^{15,29}$ This value is lower than that of a $\mathrm{Au} /$ water/Au system $\left(\mathrm{C}_{\mathrm{Au}} \approx\right.$ $20 \mu \mathrm{F} \mathrm{cm}^{-2}$ ), which implies that no bulk doping is occurring in the P3HT-biotin film. This also confirms that P3HT-biotin can be 75 used in OFET transistors in this range of potential. ${ }^{15}$

Electrical characterization of water-gated OFETs and interactions with proteins

Measurements were first carried out with deionized (DI) water as the electrolyte. A schematic cross-section of a water-gated OFET 80 is shown in Figure 3. Output and transfer curves are given in Figure 4; they are typical for a FET behavior, with a linear region at low $\mathrm{V}_{\mathrm{D}}$ and a saturation regime at higher $\mathrm{V}_{\mathrm{D}}$ (in absolute value). The mobility $\mu$ was calculated in the saturation region following the equation below.

$$
I_{D}=\left(\frac{W}{2 L}\right) \mu C\left(V_{G}-V_{T}\right)^{2}
$$




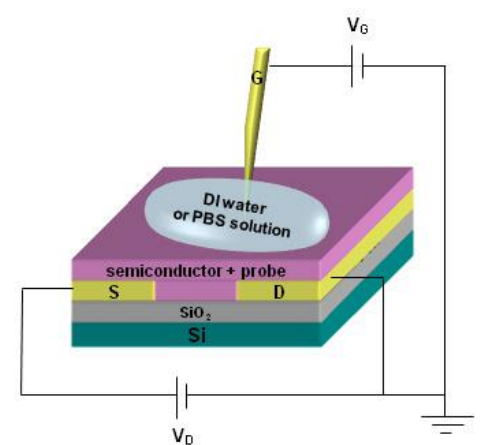

Figure 3: Schematic view of a water-gated OFET


Figure 4: Output and transfer curves for a water-gated OFET based on P3HT-biotin.

$\mathrm{C}$ is the capacitance (per unit area) of the water/P3HT-biotin double-layers and $\mathrm{W}$ and $\mathrm{L}$ the width and length of the 10 conducting channel, respectively. In our calculation, we used the value of the capacitance at low frequency $\left(3 \mu \mathrm{F} \mathrm{cm} \mathrm{cm}^{-2}\right)$.

Mobilities of up to $7.3 \times 10^{-3} \mathrm{~cm}^{2} \mathrm{~V}^{-1} \mathrm{~s}^{-1}$, threshold voltages of around $-0.1 \mathrm{~V}, I_{\text {on }} / I_{\text {off }}$ ratios of around $400-500$ and subthreshold swings of nearly $0.3 \mathrm{~V}$ per decade were obtained. These 15 results are similar to those for water-gated OFETs based on pure P3HT and on $\alpha$-sexithiophene, particularly as far as the mobility is concerned. ${ }^{15,29}$ A slight hysteresis between the forward and backward sweeps is observed on the output curves at $\mathrm{V}_{\mathrm{G}}=-0.4 \mathrm{~V}$ and above. It could be associated with charge carriers trapped at 20 the copolymer/water interface due to remaining carboxylate groups (negatively charged) in the semiconductor structure.

\section{Interactions with proteins, without repellent}

In order to evaluate the sensitivity of P3HT-biotin-based OFETs
25 to proteins, a PBS buffer ( $\mathrm{pH} 7.4$ ) was used as the electrolyte, into which streptavidin $\left(\mathrm{pI}_{\text {Streptavidin }}=5\right)$, avidin $\left(\mathrm{pI}_{\text {Avidin }}=10.5\right)$ or HSA $\left(\mathrm{pI}_{\mathrm{HSA}}=5\right)$ was added at a concentration of $0.1 \mathrm{mg} \mathrm{mL}^{-1}$. All three proteins being charged at $\mathrm{pH}=7.4$, the Debye screening length $\lambda_{D}$ must be taken into account. In PBS, the length amounts 30 to $7-8 \mathrm{~nm}$, that is, at least ten times the average proteins' dimension. This prevents most of the proteins' charges from being screened from the P3HT surface ${ }^{30}$. The results for three transistors exposed to solutions of streptavidin, avidin and HSA, respectively, are given in Figure 5. The blue curve represents the 35 current in pure PBS and the red one the current after incubation with the protein, followed by rinsing. If charges carried by the proteins were responsible for the current change, the addition of streptavidin (negatively charged). would result in a current increase and a threshold shift towards positive voltages, as
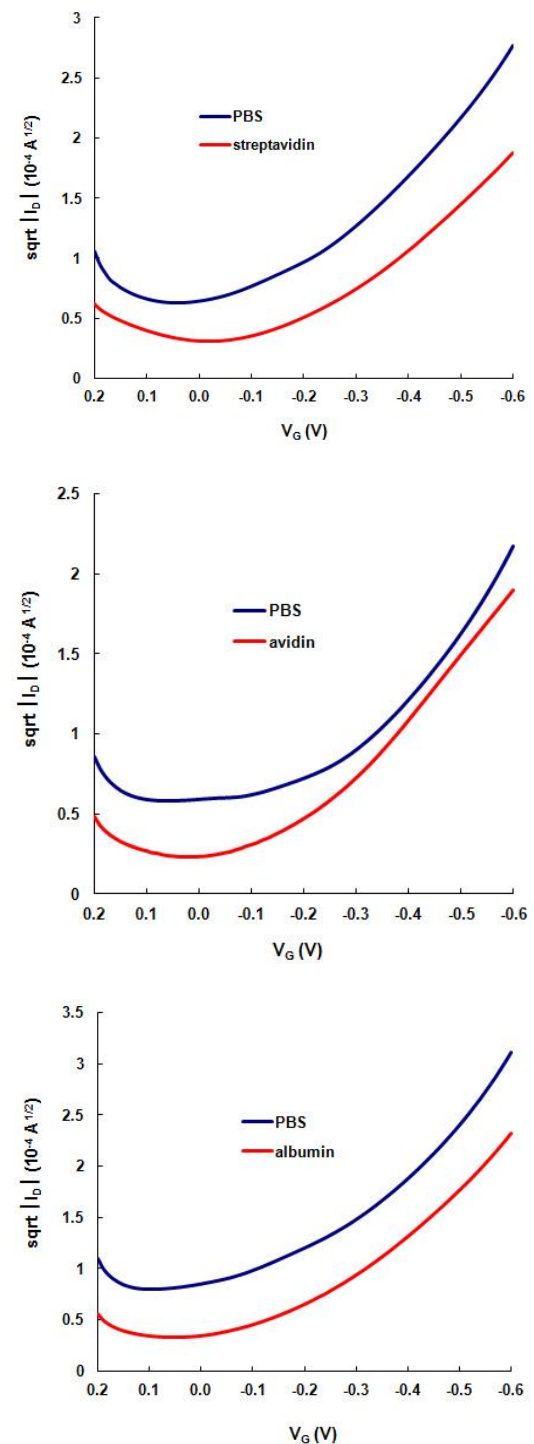

45 Figure 5: Transfer curves at saturation for sensors incorporating P3HTbiotin before (blue curves) and after (red curves) incubation with proteins

expected for a $p$-type FET $^{20}$ Conversely, the addition of avidin (positively charged) would induce a current decrease and a 
threshold shift towards negative voltages. Finally, addition of albumin would not result in any change since this protein is not able to bind biotin.

Seven devices were investigated with streptavidin and avidin 5 and six with HSA. Similar results were obtained in all cases, that is, a small shift of the threshold voltage to negative values $(-0.05$ $\mathrm{V}$ on average) and a decrease of the drain current by $55-70 \%$ for streptavidin and avidin and by $45-60 \%$ for HSA. We note that similar results (not shown here) were obtained for the three 10 proteins with a different transistor dimension $(\mathrm{L}=2 \mu \mathrm{m}$ and $\mathrm{W}=30000 \mu \mathrm{m})$. The $\Delta I_{D} / I_{D O}$ and electrical data are reported in Table 1 . We can conclude that there is no obvious discrimination between the specific proteins and HSA. This could be explained by strong non-specific interactions between all three proteins and

Table 1: $\Delta \mathrm{I}_{\mathrm{D}} / \mathrm{I}_{\mathrm{D} 0}$ and electrical figures of merit for sensors incorporating P3HT-biotin $\left(\mathrm{V}_{\mathrm{G}}=-0.6 \mathrm{~V}\right.$; Protein: $100 \mu \mathrm{g} / \mathrm{mL}$

\begin{tabular}{|c|c|c|c|c|c|}
\hline & $\begin{array}{c}I_{\text {Danalyte }} \\
(\mu \mathrm{A})\end{array}$ & $\begin{array}{c}\Delta I_{D} / I_{D 0} \\
(\%)\end{array}$ & $\begin{array}{r}\mu\left(\mathrm{cm}^{2} \mathrm{~V}^{-1} \mathrm{~s}^{-1}\right) \\
\times 10^{-4}\end{array}$ & $V_{T}(\mathrm{~V})$ & $I_{o n} / I_{o f f}$ \\
\hline strep & $0.4 \pm 0.2$ & $-64 \pm 6$ & $10 \pm 7$ & $-0.1 \pm$ & $80 \pm 50$ \\
\hline avidin & $0.12 \pm 0.09$ & $-60 \pm$ & $8 \pm 6$ & $-0.08 \pm$ & $60 \pm 20$ \\
\hline HSA & $0.1 \pm 0.1$ & $-52 \pm 7$ & $7 \pm 5$ & $-0.06 \pm 0.01$ & $50 \pm 10$ \\
\hline
\end{tabular}

the semiconductor surface, owing to the high hydrophobicity of 20 the copolymer, which consists of around $85 \%$ of P3HT, thus hiding the specific interactions between (strept)avidin and biotin.

\section{Interactions with proteins, with Tween 20 repellent}

In order to significantly decrease non-specific interactions, we 25 increased the hydrophilicity of the polymer surface by using a surfactant, Tween 20, the structure of which is given in Figure 6. Tween 20 is known to reduce non-specific and protein-protein interactions.

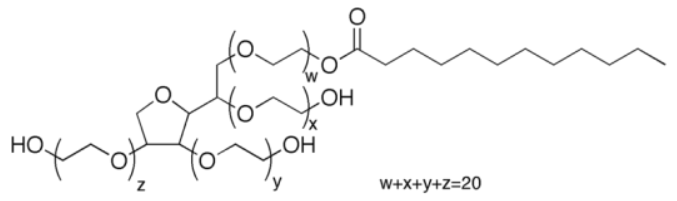

Figure 6: Structure of Tween 20

After thermal annealing and before the first measurement with PBS, P3HT-biotin-based transistors were immersed in a $0.05 \%$ $\mathrm{v} / \mathrm{v}$ solution for $15 \mathrm{~min}$ then rinsed with deionized water and 35 dried under argon. Figure 7 shows the curves obtained before and after incubation with the three proteins. As shown, the variation of the drain current is very small in all cases, meaning that no protein is able to significantly interact with the surface. Owing to the fact that the hydrophobic part of Tween 20 interacts with the 40 side chains of P3HT, the blocking effect could be explained by the steric hindrance induced by its size, so that biotin is almost inaccessible. The $\Delta I_{D} / I_{D O}$ and electrical figures of merit are reported in Table 2 .
45 Table 2: $\Delta I_{D} / I_{D 0}$ and electrical figures of merit for sensors incorporating transistors based on P3HT-biotin and treated with Tween 20

\begin{tabular}{cccccc}
\hline & $\begin{array}{c}I_{\text {Danalyte }} \\
(\mu \mathrm{A})\end{array}$ & $\begin{array}{c}\Delta I_{D} / I_{D 0} \\
(\%)\end{array}$ & $\begin{array}{c}\mu\left(\mathrm{cm}^{2} \mathrm{~V}^{-1} \mathrm{~s}^{-1}\right) \\
\times 10^{-4}\end{array}$ & $V_{T}(\mathrm{~V})$ & $I_{\text {on }} / I_{\text {off }}$ \\
\cline { 2 - 6 } streptavidin & $0.7 \pm 0.2$ & $0 \pm 2$ & $4 \pm 2$ & $0.03 \pm 0.02$ & $80 \pm 20$ \\
avidin & $0.09 \pm 0.09$ & $4 \pm 4$ & $8 \pm 2$ & $0.02 \pm 0.02$ & $75 \pm 20$ \\
HSA & $0.2 \pm 0.1$ & $-6 \pm 5$ & $5 \pm 3$ & $0.03 \pm 0.01$ & $50 \pm 15$ \\
\hline
\end{tabular}

\section{Interactions with proteins, with Tween 20 repellent}

We selected 1-octanol instead of Tween 20 because of its similar 50 hydrophobic side and smaller hydrophilic head, thus allowing a better accessibility to biotin. Figure 8 shows the results obtained with 1-octanol, before and after incubation with the three proteins. This time, there is almost no change for the drain current when HSA is added (although a current decrease of $25 \%$ 55 was observed in a few cases), whereas incubation with both streptavidin and avidin leads to a significant current decrease. This indicates that 1-octanol is able to decrease non-specific
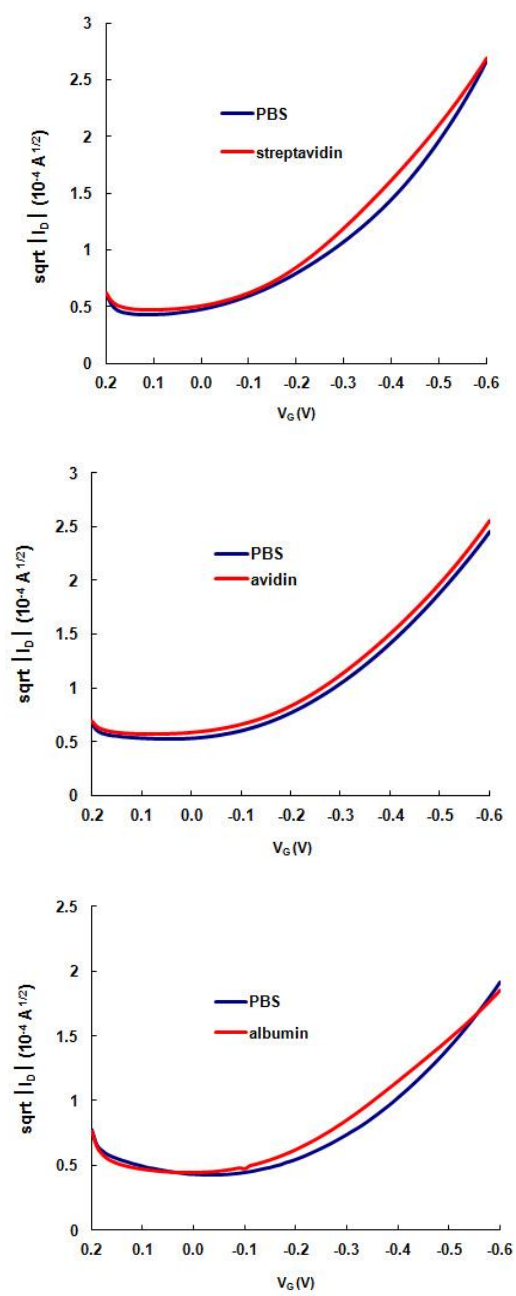

Figure 7: Transfer curves at saturation for P3HT-biotin-based transistors treated with Tween 20 before and after incubation with proteins

interactions and thus induce a specific response. Moreover, the ${ }_{65}$ decrease of the drain current for streptavidin and avidin is lower than in the case of the copolymer without repellent, showing that 
only specific binding is transduced. The $\Delta I_{D} / I_{D 0}$ and electrical data are reported in Table 3 . We do not observed the expected response in terms of shift of the threshold voltage and variation of the drain current upon interaction with streptavidin (negatively 5 charged) or avidin (positively charged). Instead, a decrease of the drain current occurs in both cases. We believe that, unlike dielectric-gated transistors, where charge effects are predominant, water-gated transistors are rather sensitive to capacitive effects.

We have carried out preliminarily electrochemical impedance 10 spectroscopy measurements (not shown here) in a three-electrode configuration and found that a significant decrease of the doublelayer capacitance does indeed occur when (strept)avidin is interacting with biotin.
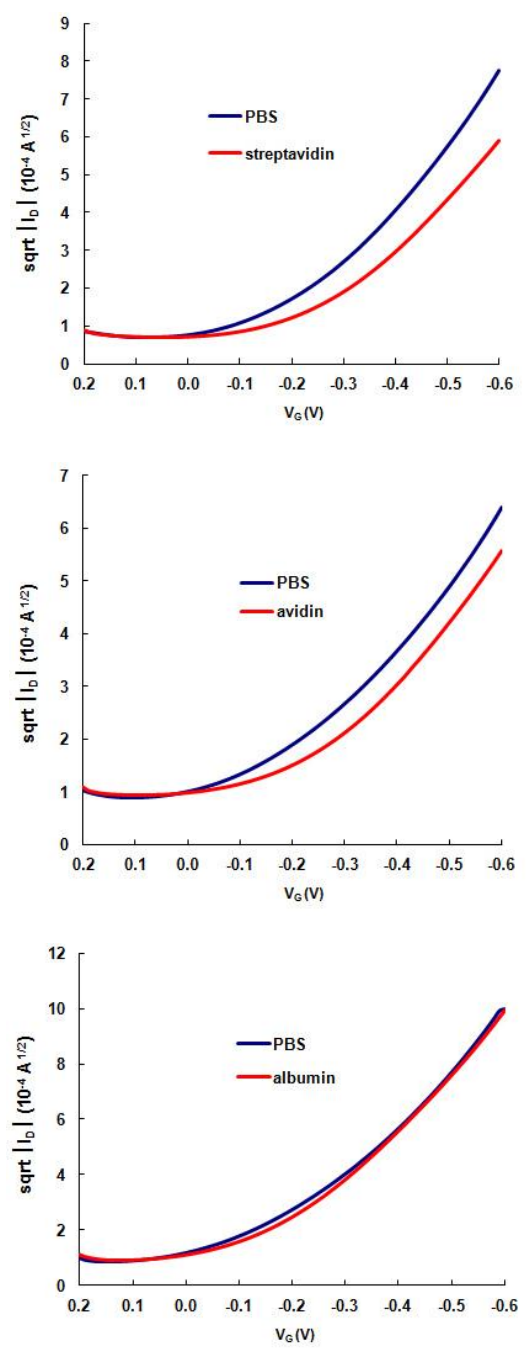

Figure 8: Transfer curves at saturation for P3HT-biotin-based transistors treated with 1-octanol before and after incubation with proteins

These results are not sufficient to quantitatively explain the 20 observed drain current changes, but they are in qualitative agreement.

\section{Conclusions}

In the present work, a biosensor based on a water-gated OFET is described. The semiconductor element consists of a random 25 copolythiophene derived from P3HT, bearing $\mathrm{COOH}$ and biotin groups. Two repellent molecules (Tween 20, 1-octanol) were evaluated to minimize the non-specific binding of proteins such as HSA. As a proof-of-concept, avidin and streptavidin were detected through a change of the drain current and a slight shift of 30 the threshold voltage. This behavior is attributed to changes in the double-layer capacitance rather than to charges carried by the target molecules. Work is currently in progress to extend this work to other repellent agents like polyethylene glycol. The length of the spacer between the thiophene ring and biotin will

35

Table 3: $\Delta I_{D} / I_{D O}$ and electrical figures of merit for sensors incorporating transistors based on P3HT-biotin and treated with 1-octanol

\begin{tabular}{|c|c|c|c|c|c|}
\hline & $\begin{array}{c}I_{\text {Danalyte }} \\
(\mu \mathrm{A})\end{array}$ & $\begin{array}{c}\Delta I_{D} / I_{D O} \\
(\%)\end{array}$ & $\begin{array}{r}\mu\left(\mathrm{cm}^{2} \mathrm{~V}^{-1} \mathrm{~s}^{-1}\right) \\
\times 10^{-4}\end{array}$ & $V_{T}(\mathrm{~V})$ & $I_{o n} / I_{o f f}$ \\
\hline stre & $0.6 \pm 0.2$ & $-35 \pm 10$ & $3 \pm 2$ & $-0.05 \pm 0.02$ & $80 \pm 2$ \\
\hline avidin & $0.5=$ & $-31 \pm 7$ & $5 \pm 2$ & $-0.07 \pm$ & $75 \pm 20$ \\
\hline HSA & $0.55 \pm 0.2$ & $-13 \pm 12$ & $3 \pm 3$ & $-0.05 \pm 0.04$ & $50 \pm 15$ \\
\hline
\end{tabular}

also be considered, as well as the percentage of biotin groups. 40 Simplicity of fabrication and very low voltage of operation (-0.6 V) make water-gated OFET particularly interesting for biosensing applications.

\section{Acknowledgements}

This work is part of the BioEGOFET FP7 project (Grant ${ }_{45}$ Agreement $\mathrm{n}^{\circ} 248728$ ) and financial support from the European commission is gratefully acknowledged.

\section{References}

1. A. N. Sokolov, M. E. Roberts, Z. Bao, Mater. Today, 2009, 12, 12-20.

2. L. Kergoat, B. Piro, M. Berggren, G. Horowitz M.C. Pham, Anal. 50 Bioanal. Chem., 2012, 402, 1813-1826

3. B. Crone, A. Dodabalapur, A. Gelperin, L. Torsi, H. E. Katz, A. J. Lovinger, Z. Bao, Appl. Phys. Lett., 2001, 78, 2229-2231.

4. J. Huang, J. Miragliotta, A. Becknell, H. E. Katz, J. Am. Chem. Soc., 2007, 129, 9366-76.

55 5. L. Torsi, G. M. Farinola, F. Marinelli, M. C. Tanese, O. H. Omar, L. Valli, F. Babudri, F. Palmisano, P.G. Zambonin, F. Naso, Nat. Mater., 2008, 7, 412-417.

6. T. Someya, A. Dodabalapur, A. Gelperin, H. E. Katz, Z. Bao, Langmuir, 2002, 18, 5299-5302.

60 7. M. D. Angione, S. Cotrone, M. Magliulo, A. Mallardi, D. Altamura, C. Giannini, N. Cioffi, L. Sabbatini, E. Fratini, P. Baglioni, G. Scamarcio, G. Palazzo, L. Torsi, Proc. Natl. Acad. Sci. USA, 2012, 109, 6429-6434.

8. M. D. Angione, R. Pilolli,S. Cotrone, M. Magliulo, A. Mallardi, G.

65 Palazzo, L. Sabbatini, D. Fine, A. Dodabalapur, N. Cioffi, L. Torsi, Mater. Today, 2011, 14, 424-433.

9. M. E. Roberts, S. C. B. Mannsfeld, N. Queralto, C. Reese, J. Locklin, W. Knoll, Z. Bao, Proc. Natl. Acad. Sci. USA, 2008, 105, 12134 12139.

70 10. L. Kergoat, B. Piro, M. Berggren, G. Horowitz, M. C. Pham, Anal. Bioanal. Chem., 2012, 402, 1813-1826.

11. H. U. Khan, M. E. Roberts, O. Johnson, R. Förch, W. Knoll, Z. Bao, Adv. Mater., 2010, 22, 4452-4456.

12. H. U. Khan, J. Jang, J. J. Kim, W. Knoll, J. Am. Chem. Soc., 2011 133, 2170-2176.

13. H. U. Khan, M. E. Roberts, W. Knoll, Z. Bao, Chem. Mater., 2011, 23, 1946-1953.

14. G. Scarpa, A. L. Idzko, A. Yadav, S. Thalhammer, Sensors, 2010, 10 2262-2273.

80 15. L. Kergoat, L. Herlogsson, D. Braga, B. Piro, M. C. Pham, X. Crispin, M. Berggren, G. Horowitz, Adv. Mater., 2010, 22, 2565-2569. 
16. L. Kergoat, B. Piro, M. Berggren, M. C. Pham, A. Yassar, G. Horowitz, Org. Electron., 2012, 13, 1-6.

17. M. D. Savage, G. Mattson, S. Desai, G. W. Nielander, S. Morgensen, E. J. Conklin, Avidin-Biotin Chemistry: A Handbook, Pierce Chemical Co., 1992.

18. M. Wilchek, E. A. Bayer, Anal. Biochem., 1988, 171, 1-32.

19. M. Wilchek, E. A. Bayer, Avidin-Biotin Technology, ed. J. N. Abelson and M. I. Simon, San Diego, CA, 1990.

20. C. Y. Hsiao, C. H. Lin, C. H. Hung, C. J. Su, Y. R. Lo, C. C Lee, H.

10 C. Lin, F. H. Ko, T. Y. Huang, Y. S. Yang, Biosens. Bioelectron., 2009, 24, 1223-1229.

21. A. Star, J. C. P. Gabriel, K. Bradley, G. Grüner, Nano Lett., 2003, 3, 459-463.

22. L. Kumpumbu-Kalemba, M. Leclerc, Chem. Commun., 2000, 1847151848.

23. H. Zhou, Y. Tang, J. Zhai, S. Wang, Z. Tang, L. Jiang, Sensors, 2009, 9, 1094-1107.

24. F. Mouffouk, S. J. Higgins, S. J. Brown, N. Sedghi, B. Eccleston, S. Reeman, Chem. Commun., 2004, 2314-2315.

20 25. S. C. Lim, Y. S. Yang, S. H. Kim, Z. S. Kim, D. H. Youn, T. Zyung, J.Y. Kwon, D. H. Hwang, D. J. Kim, ETRI Journal, 2009, 31, 647652.

26. C. Suspène, L. Miozzo, J. Choi, R. Gironda, B. Geffroy, D. Tondelier, Y. Bonnassieux, G. Horowitz, A. Yassar, J. Mater. Chem., 2012, 22, 4511-4518.

27. J. P. Ferraris, A. Yassar, D. C. Loveday, M. Hmyene, Opt. Mater., 1998, 9, 34-42.

28. M. C. Iovu, E. E. Sheina, R. R. Gil, R. D. McCullough, Macromolecules, 2005, 38, 8649-8656.

30 29. F. Buth, D. Kumar, M. Stutzmann, J. A. Garrido, Appl. Phys. Lett., 2011, 98, 153302-1,153302-3.

30. E. Stern, R. Wagner, F. J. Sigworth, R. Breaker, T. M. Fahmy, M. A. Reed, Nano Lett., 2007, 7, 3405-3409. 